\title{
DIAGNÓSTICO DE RESISTENCIA A ORGANOFOSFO- RADOS, PIRETROIDES SINTÉTICOS, AMIDINAS E IVER- MECTINAS \\ EN LA GARRAPATA RHIPICEPHALUS MICROPLUS EN FINCAS DE PRODUCTORES DE LECHE DE COSTA RICA
}

\author{
Alvarez, $\mathrm{V}^{1,2}$ \& HernandeZ, $\mathrm{V}^{1}$
}

\begin{abstract}
RESUMEN
Entre marzo y octubre del 2009 se realizó en 109 fincas de leche de Costa Rica un estudio para determinar la resistencia de la garrapata Rhipicephalus (Boophilus) microplusa organofosforados, piretroides sintéticos, amidinas e ivermectinas, el cual consistió en la recolección de hembras adultas repletas y el procesamiento de las larvas obtenidas a nivel de laboratorio, por medio de pruebas específicas. Asimismo se hizo una encuesta a los productores sobre manejo de los acaricidas. Entre los hallazgos más relevantes encontramos: el sistema de control es el químico; el principal método de aplicación es aspersión con bomba de espalda; hay un sobre control de garrapatas; la cantidad de animales bañados por bomba fue superior a la recomendada; hayuna serie de fallas al momento del baño (falta de sistematicidad, ausencia de premezcla, se bañaban los animales sueltos); los niveles de infestación no justificaban la fuerte presión sobre la población. Se establece, por vez primera en Costa Rica, un estimado de costos de tratamiento contra garrapatas. Hubo niveles variados de resistencia a todas las moléculas, encontrando en el $100 \%$ de las fincas niveles muy altos de resistencia a los piretroides sintéticos; prácticamente un $25 \%$ en el caso de fosforados, casi un $50 \%$ para las amidinas y cerca de un 7\% en relación con las ivermectinas.
\end{abstract}

Palabras claves: Rhipicephalusmicroplus, garrapatas, resistencia, acaricidas, Costa Rica.

\section{SUMMARY}

Diagnostic for resistance to organophosphates, synthetic pyrethroids, amidines and ivermectines, in rhipicephalus microplus ticks on dairy farms in Costa Rica.

In order to determine the resistance of Rhipicephalus (Boophilus) microplus ticks to organophosphates, pyrethroids, amidine and ivermectin, a study to was carried out between March and October 2009 in 109 dairy farms from Costa Rica. Replete tick females were collected at the farms. In the laboratory, the larva were obtained by specific methods. Besides, a survey was applied to

1.- Control e Investigación de Ixodicidas, LANASEVE, SENASA.

2.- Autor Corresponsal: viacal@racsa.co.cr Apartado Postal: 11965-1000. San José, Costa Rica.

Manuscrito recibido el 26 de julio de 2010 y aceptado para su publicación el $1^{\circ}$ de diciembre de 2010. 
the farmers about the management of acaricides. Some of the most important findings were: the system for control is chemical; the most frequent method of applications is with manual aspersion pumps; there is an over-control of ticks; the amount of animals treated by pump was greater than recommended by the manufacturer; there were some very frequent mistakes at the application of the drugs (lack of systematicity, absence of premixing, aspersion of animals walking); the levels of infestation did not justify the strong pressure on the population. For the first time it is established, in Costa Rica, an estimation of the costs for ticks control. There were several levels of resistance to all drugs, especially for synthetic pyrethroids with high resistance in $100 \%$ of farms; $25 \%$ to organophosphates, almost $50 \%$ to amidine and $7 \%$ to ivermectin.

Key words: Rhipicephalusmicroplus, ticks, resistance, acaricides, Costa Rica. 